\title{
Efekt intervenčního programu na vybrané kondiční a koordinační schopnosti u sledovaných jedinců v období senia (př́ípadová studie)
}

\section{The effect of intervention program on selected condition and coordination abilities at observed individuals at the period of seniority (case study)}

\author{
Lenka Svobodová, Jitka Kopřivová, Dagmar Šimberová
}

Fakulta sportovních studií Masarykovy univerzity, Brno

\begin{abstract}
Abstrakt
Případová studie se zabývá vlivem šestiměsičního intervenčního programu na změnu úrovně statické a dynamické rovnováhy, orientace $v$ prostoru a síly dolních končetin u vybraných jedincù vobdobí sénia. Tyto schopnosti považujeme za limitující v životě seniorů. Soubor tvořili čtyři jedinci, dva muži a dvě ženy ve věku 88, 83, 81, 82 let. Potřebná data $k$ posouzení úrovně sledovaných pohybových schopností jsme ziskali pred a po ukončení pohybové intervence pomocí šesti vybraných standardizovaných motorických testů. Intervenční pohybový program trval 6 měsíců, byl realizován dvakrát týdně po 60 min. Hledali jsme informace ohledně zdravotního stavu a životního stylu, které by mohly sledované schopnosti u jednotlivých osob ovlivňovat. U tři jedincủ se i po cíleném cvičení zhoršila úroveñ statické rovnováhy. Tato schopnost se ukázala jako nejvíce ovlivnitelná zdravotními problémy a involučním procesem. U žádného jedince nedošlo ke snižení úrovně dynamické rovnováhy, orientace v prostoru a síly dolních končetin. Výsledky nelze zevšeobecňovat, ale jsou di̊kazem, jak lze individuálně zvolenou intervencí přispět ke kvalitě života.
\end{abstract}

\begin{abstract}
The case study deals with the influence of six months intervention program onto the change of the level of static and dynamic balance, orientation in the space and the strength of lower limbs at selected individuals in the period of seniority. These abilities are considered to be limiting in the life of seniors. The complex was created by four individuals, two men and two women at the age of $88,83,81,82$. The needed datas to judge the level of monitoring locomotive abilities we obtained before and after finishing locomotive intervention by the help of six choosen standard motoric test. This intervention locomotive programme lasted for six months, it was carried out twice a week always 60 minutes. We were looking for some information regarding state of health and lifestyle, which could influence observed abilities at individuals. The level of static balance got worse at three individuals also after pointed exercises. This ability was proved as the most susceptible by health problems and by evolutionary process. At any of individuals wasn't proved any decreasing of the level of dynamic balance, space orientation or the strength of lower limbs. It is not possible to generalize the findings but they are the proves of contribution to the quality of life by the individually choosen intervention.
\end{abstract}

Klićová slova: $\quad$ senior, kondiční schopnost, koordinační schopnost, intervenční program Key words: $\quad$ senior, condition abilities, coordination abilities, intervention programme

\section{ÚVOD}

V současné době dochází ke změnám složení lidské populace. S prodlužující se délkou života přibývá lidí seniorského věku. Podle statistických prognóz má být 21.století stoletím seniorů. Poprvé v historii bude žít na zemi více lidí starších 60 let než lidí mladších 15 let. Pro společnost to znamená zvýšenou pozornost geriatrické péči (Klevetová, Dlabačová 2008).

Wilhelm et al. (2003) chápe stáří jako zákonitou etapu ontogenetického vývoje, i když obtížně definovatelnou. Stárnutí postihuje orgánové systémy a tělesné funkce již od narození, zřetelně od 20 let. Z morfofukčních involučních změn vyplývá zvýšená únavnost starších osob, delší doba regenerace, pokles 
adaptability a ekonomiky práce jednotlivých tělesných systémů. Z pohybových schopností se nejdříve začíná zhoršovat pohyblivost (již od 15 let), dále schopnost koordinace (40 let), následuje pokles rychlosti a nejdéle se udržuje vytrvalost (Havlíčková et al. 2004).

V současné době se setkáváme s mnoha dynamickými teoriemi stárnutí. Např. Rheinwaldová (1999) chápe stárnutí jako proces, mající do určité míry schopnost regenerace. Činnost udržuje, posiluje a rozvíjí funkce lidského těla i mysli. Nečinností se vytrácejí.Velikáni Pablo Picasso, Giuseppe Verdi, Jaroslav Seifert a další vytvářející svá proslulá díla i v pozdním věku potvrzují, že činorodost a zájem prodlužují aktivní věk. Díla seniorů vycházejí z bohatých životních zkušeností a osobní vyrovnanosti.

Problematikou zkvalitnění života seniorů se zabývá Světová zdravotnická organizace v programu „Zdraví 21“, jehož cílem je pozvednout problematiku zdraví mezi nejvyšší hodnoty. Jedním z hlavních problémů seniorského věku je právě motivace. Programy pro seniory by se neměly zabývat samotnou fyzickou aktivitou, ale cíleně vytvářet pozitivní prožitky a zvyšovat chut' k další aktivitě.

Zimmelová (2005) se zabývá problematikou pohybové aktivity seniorů jako prevence pádů. Hlavním mechanismem pádů ve stárí je snížená schopnost rychlé posturální adaptace na měnící se a ztížené podmínky chůze, jak je tomu při vstávání ze sedu, při chůzi ze schodů apod. Již Štilec (2004) ve svém výzkumu posuzoval koordinaci a obratnost u vybrané skupiny seniorů. Zjistil, že tyto schopnosti mají kladný vliv pro ovládání těžiště těla. Prováděli pravidelně specifická cvičeni zaměřená na stabilitu, která byla zařazovaná v závěru cvičební hodiny. $\mathrm{V}$ tř́letém experimentu čtvrtina seniorů potvrdila zlepšeni těchto schopností. Vznikla u nich větší sebejistota při vykonávání domácích povinností (úklid, sebeobsluha, atd.). Vlivem pohybové aktivity na kognitivní a mnestické funkce u osob starších 60 let se zabývali MUDr. Jiří Dolina a doc. PaedDr. Jitka Kopřivová, CSc., v Projektu podpory zdraví (2002-2003). Prokázali, že vhodným a pravidelným cvičením lze tyto schopnosti zlepšit.

$\mathrm{Na}$ základě literatury a získaných poznatků jsme vytvořily intervenční program zaměřený právě na udržení stávající úrovně, př́ípadně rozvoj vybraných kondičních a koordinačních schopností. Z kondičních schopností jsme vybrali sílu (dolních končetin) a krátkodobou vytrvalost. Sílové schopnosti jsou $\mathrm{v}$ důsledku involučního procesu ovlivňovány úbytkem svalové hmoty. Vytrvalostní schopnosti ubývají ze všech pohybových schopností nejpomaleji. Z koordinačních schopností jsme vybrali schopnosti rovnováhové a orientační. Rovnováha, síla dolních končetin a orientace v prostoru jsou důležité z hlediska prevence pádi̊.

Chytráčková (1985) popisuje prostorověorientační schopnosti jako schopnost zhodnotit časové a prostorové vztahy objektů mezi sebou (vzdálenost, směr atd.) ve vztahu k sobě, k poloze vlastního těla, resp. jeho částí. Jde o schopnost rychle a přesně zachytit všechny důležité informace pohybové činnosti. Velký význam má tzv. periferní vidění, které umožňuje proces prostorové orientace zpřesnit a urychlit. Nejčastějším případem špatného hodnocení prostoru je nepřesnost hodnocení vzdálenosti nějakého předmětu. Přesnost tohoto hodnocení klesá se zvětšováním vzdálenosti.

Šimonek, Zapletalová (1985) uvádějí, že orientační schopnost je schopnost určit a změnit polohu těla, ř́dit pohyby těla v prostoru a čase a v souladu s vnějším prostředím. Rozhodující význam pro tuto schopnost má zrakový a vestibulární aparát. Rovnováhová schopnost je schopnost udržet tělo nebo jeho části v relativně labilní, rovnovážné poloze a tuto polohu, je-li narušená vlivem vnějších sil, obnovit. Tato schopnost je nejvíce závislá na činnosti vestibulárního aparátu. Její úroveň ovlivňují ještě další vnější a vnitřní faktory, např. Fetz (1987) a Klárová (1993) uvádí stres, alkohol, kofein a fyzické zatížení. Udržení, popř. zlepšení úrovně pohybových schopností umožní seniorům žít plnohodnotný život, být soběstační. Některé studie (Dropčová 1987, Klárová 1999, Javůrek 1988, Moenhle 1987, Kostadinová 1989 a jiní) dokazují, že rovnováhové schopnosti nejsou ovlivňovány rozměry těla ani pohlavím, naopak věk je pro tuto schopnost významným faktorem. Involuční změny související s věkem jsou do jisté míry ovlivnitelné pohybovou aktivitou a aktivním životním stylem. Zpomalení involuce vlivem intervenčních pohybových programů již ve svých studiích prokázali např. Štilec (2004), Kopřivová (2005).

Cílem př́spěvku je posouzení vlivu intervenčního programu na sledované motorické schopnosti u čtyř vybraných jedinců. 


\section{METODIKA}

Základní výzkumnou metodologií naší práce je případová studie. Hendl (2005) popisuje případovou studii jako detailní studium jednoho nebo několika málo prrípadů. Jde o zachycení složitosti prrípadu, o popis vztahů v jejich celistvosti.

Soubor obsahuje čtyři záměrně vybrané osoby (dva muži, dvě ženy). Intervenční pohybový program jsme zaměřili na udržení stávající úrovně, případně zlepšování úrovně statické a dynamické rovnováhy, síly dolních končetin, orientace $\mathrm{v}$ prostoru. Tyto aspekty dle našich výzkumů nejvíce ovlivňují život seniorů.

Intervenční program obsahoval cvičení pro rozvoj správného držení těla, zahrnoval adekvátní posílení a protažení velkých svalových skupin (15 min). S využitím balančních plošin (overball, bosu, čočky) byl kladen důraz na udržení úrovně statické rovnováhy (15 min). Taneční krokové variace s hudebním doprovodem sloužily $\mathrm{k}$ uvědomělému získávání dynamických rovnováhových dovedností a prostorové orientace $(30 \mathrm{~min})$. Hudba nám nabídla úzké propojení rytmu a pohybu, ovlivňovala limbický systém a pozitivní emoce. Intervenční program jsme zařadili do pravidelného cvičení seniorů $2 \mathrm{x}$ týdně po dobu 60 minut. Program probíhal půl roku (listopad 2008-červen 2009) v prostorách penzionu pro seniory.

\section{Charakteristika výzkumného souboru}

Výzkumný soubor tvořili čtyři záměrně vybraní senioři (dva muži a dvě ženy). Společným znakem vybraných seniorů je aktivní způsob života, kromě pravidelného cvičení navštěvují přednášky, chodí na vycházky.

První testovaná osoba (dále jen TO) se narodila v roce 1921, mužského pohlaví, váha 74 kg, výška $160 \mathrm{~cm}$, BMI 28,9. Během života hrála u jedince pohybová aktivita výraznou roli v zábavě i v zaměstnání. Sportu se sice věnoval spíše rekreačně, ale pravidelně pěstoval turistiku. Žije ve vlastní domácnosti s manželkou. Trpí částečnou nedoslýchavostí, prodělal těžký úraz (1960) a operaci z důvodu krvácení do žlučníku. V současné době se cítí celkem dobře. Je milý, usměvavý, stále pozitivně naladěný, spíše uzavřený. Rád pracuje na zahradě. Na cvičení chodil pravidelně, byl snaživý. Problémem probanda byla jeho nedoslýchavost. Neslyšel všechny pokyny k cvičení a pouze kopíroval ostatní.

TO 2 se narodila v roce 1926, mužského pohlaví, váha $99 \mathrm{~kg}$, výška $182 \mathrm{~cm}$, BMI 29,9. Žije sám ve vlastním panelákovém bytě, navštěvuje prítelkyni, má jediného syna, se kterým však nemá dobré vztahy. Mezi jeho současné zdravotní problémy patří dna, nedostatečná činnost štítné žlázy, vysoký krevní tlak, nadváha. $\mathrm{V}$ mládí hrál závodně házenou, později rekreačně volejbal a až do padesáti let pravidelně plaval. V současné době chodí na procházky a v sezóně pracuje na zahradě. Je společenský, komunikativní. Proband přistupoval k programu jako ke společenské události. Chodil pravidelně, u cvičení vnímal spíše společenský kontakt.

TO 3 se narodila v roce 1928, ženského pohlaví, váha 63 kg, výška $163 \mathrm{~cm}$, BMI 23,7. Žije v penzionu pro seniory, $2 \mathrm{x}$ týdně si sama vaří, má pěkný vztah s vnučkami a ráda je navštěvuje, je velmi činorodá, nemá ráda domácí práce, proto částečně využívá služeb penzionu. Celý život pravidelně ráno cvičí (30 min). Je společenská, komunikativní a sdílná. Hodně času věnuje péči o svůj zevnějšek. V současné době trpí vysokým krevním tlakem, arytmií, problémy se srdeční chlopní (nedomykavost). Má operován šedý zákal a občas špatně usíná. Na intervenční program chodila téměř pravidelně (zřídka IP vyměnila za jinou aktivitu - přednáška, divadlo). Cvičila velmi opatrně. Měla obavu z každého nového pohybu.

TO 4 se narodila v roce 1927, ženského pohlaví, váha 81 kg, výška $165 \mathrm{~cm}$, BMI 29,8. Žije sama ve vlastní domácnosti, je vysokoškolsky vzdělaná, prodělala infarkt myokardu (1995), krevní výron na sítnici levého oka. V současné době má srdeční trojitý by-pass po operaci chlopně, cévní a zrakové potíže a nadváhu. Ráda chodí do knihovny, poslouchá hudbu a pracuje na zahradě. V mladším věku se věnovala józe a bruslení. Je optimistická a má ráda kolem sebe stejně smýšlející lidi. Probandka chodila na cvičení pravidelně, kromě jednoho třítýdenního výpadku způsobeného operací šedého zákalu. Je spíše klidnější povahy a tak přistupovala i ke cvičení.

TO 1 a TO 2 byly vybrány jako jediní zástupci mužského pohlaví, kteří absolvovali celý půlroční program, včetně testování. TO 3 žije jako jediná $\mathrm{z}$ naší skupiny cvičících seniorů v penzionu pro seniory. TO 4 měla nejhorší výsledky ze všech účastníků intervenčního programu. 


\section{Metody získávání dat}

Ze sociologických metod jsme vybraly anketu a řízený rozhovor pro zjištění bližších informací o jednotlivých probandech a vytvoření kazuistiky. Během intervenčního programu jsme používaly metodu pozorování pro zjištění př́stupu k intervenčnímu programu.

$\mathrm{Z}$ motorických testů jsme použily tyto testy:

- Test statické rovnováhy na stabilometrické plošině (Měkota 1979). TO stály 10 s s otevřenýma očima a 10 s se zavřenýma očima. Měřily jsme celkovou dráhu centra zatížení (COP) v mm. Čím jsou naměřené hodnoty nižší, tím je úroveň statické rovnováhy vyšší.

- Foot up and go test (Rikli; Jones 2001). Testem byla zjištována úroveň orientace v prostoru a dynamické rovnováhy. TO seděly na židli s dlaněmi na stehnech. Na stanovený signál vstaly, obešly kužel ve vzdálenosti $2,44 \mathrm{~m}$ a vrátily se do sedu na židli. Měřili jsme čas (s). TO měly 2 pokusy, počítaly jsme lepší pokus.

- Chair stand test (Rikli; Jones 2001) pro zjištování úrovně síly dolních končetin a dynamické rovnováhy. TO opakovaně vstávaly a sedaly na židli, bez pomoci rukou, po dobu 30s. Měřily jsme počet opakování.

- Step test (Rikli; Jones 2001). Pomocí testu jsme zjištovaly úroveň dynamické síly dolních končetin, dynamické rovnováhy a krátkodobé vytrvalosti. Ze stoje spojného TO po dobu 2 min zvedaly střídavě dolní končetiny skrčmo do předepsané výšky. Výšku tvořil střed mezi čéškou a kyčelní kostí jednotlivce. Zjištovaly jsme počet opakování.

- Side step test (Měkota 1979). Prostř̌ednictvím testu jsme zjištovaly úroveň dynamické rovnováhy a orientaci v prostoru. TO prováděly přísunné kroky stranou na vzdálenost $4 \mathrm{~m}$ (tam vpravo a zpět vlevo). Měřily jsme dobu (s), za kterou TO přešly $3 x$ tam a zpět.

- Test dynamické rovnováhy pomocí dvou digitálních kamer a softwaru SIMI Motion. TO prošly $\mathrm{z}$ bodu A do bodu B ve vzdálenosti $6 \mathrm{~m}$ nejprve s otevřenýma očima, poté se zavřenýma očima. Pro digitalizaci záznamu byly použity dva body - hlava a centrum pánve. Měřily jsme celkovou dráhu centra pánve a hlavy a sledovaly vychýlení.

\section{VÝSLEDKY A DISKUSE}

Tab.1 Výsledky testu statické rovnováhy (otevřené oči) - stabilometrie

\begin{tabular}{|c|c|c|c|}
\hline TO & I. měření & II. měření & změna mezi I.-II. měřením \\
\hline & COP/mm & $\mathrm{COP} / \mathrm{mm}$ & \\
\hline TO 1 & 438,2 & 389,6 & zlepšení \\
\hline TO 2 & 81,1 & 145,1 & zhoršení \\
\hline TO 3 & 85,6 & 89,7 & zhoršení \\
\hline TO 4 & 46,7 & 158,7 & zhoršení \\
\hline
\end{tabular}

Jak vyplývá z Tab.1, zlepšení ve statické rovnováze jsme zaznamenali jen u TO 1, u ostatních nastalo zhoršení. Zhoršení TO 2 připisujeme také nedostatečné trpělivosti při cvičeních zaměřených na statickou rovnováhu. TO 2 byla při cvičení nesoustředěná a neklidná. Spíše než o samotný účinek cvičení se zajímala o sociální kontakt. I přes cíleně zaměřený intervenční program se nám (u TO 2, TO 3, TO 4) nepodařilo udržet úroveň statické rovnováhy. Problémy se statickou rovnováhou mohou být způsobeny involučními změnami a také léky na vysoký krevní tlak, které užívají všichni probandi. 
Tab.2 Výsledky testu statické rovnováhy (zavřené oči) - stabilometrie

\begin{tabular}{|c|c|c|c|}
\hline TO & I. měření & II. měření & změna mezi I.-II. měřením \\
\hline & $\mathrm{COP} / \mathrm{mm}$ & $\mathrm{COP} / \mathrm{mm}$ & \\
\hline TO 1 & 544,2 & 482 & zlepšení \\
\hline TO 2 & 150,2 & 330,4 & zhoršení \\
\hline TO 3 & 78,3 & 146,8 & zhoršení \\
\hline TO 4 & 53 & 329,3 & zhoršení \\
\hline
\end{tabular}

Největšího zhoršení úrovně statické rovnováhy se zavřenýma očima jsme zaznamenali u TO 4 (Tab. 2). Zhoršení si mimo jiné vysvětlujeme problémy se zrakovým aparátem a nadváhou (a s nimi souvisejícími problémy - vysoký krevní tlak atd.). Výsledky ukazují, že statická rovnováha, zejména se zavřenýma očima, se s věkem značně zhoršuje. Intervenční program byl cíleně zaměřen také právě na statickou rovnováhu. Zjištujeme, že udržet ty to schopnosti je velmi náročné. $O$ to pozitivněji na nás působí zlepšení u TO 1. Vysoké hodnoty vstupních testů přisuzujeme částečné nedoslýchavosti. Zlepšení lze zdůvodnit pozitivním př́stupem k intervenčnímu programu a vhodnému výběru cviků pro její osobní parametry (úroveň motorických schopností).

Tab. 3 Výsledky testu orientace v prostoru a dynamické rovnováhy - Food up and go test

\begin{tabular}{|c|c|c|c|}
\hline TO & I. měření & II. měření & změna mezi I.-II. měřením \\
\hline & čas/s & čas/s & \\
\hline TO 1 & 7,7 & 7,5 & zlepšení \\
\hline TO 2 & 8 & 7,7 & zlepšení \\
\hline TO 3 & 7,2 & 6,8 & zlepšení \\
\hline TO 4 & 7,6 & 7,4 & zlepšení \\
\hline
\end{tabular}

V dynamické rovnováze a orientaci v prostoru nedošlo k žádné negativní změně (Tab. 3), což vzhledem $\mathrm{k}$ věku považujeme za uspokojivý výsledek. Je zřejmé, že intervenční program byl vhodně sestaven a realizován právě vzhledem $\mathrm{k}$ uvedené pohybové schopnosti. Podíl na zlepšení dynamické rovnováhy spolu s prostorovou orientací přisuzujeme také aktivnímu způsobu života probandů. Test blízce souvisí s každodenními činnostmi.

Tab. 4 Výsledky testu síly dolních končetin a dynamické rovnováhy - Chair stand test

\begin{tabular}{|c|c|c|c|}
\hline TO & I.měření & II.měření & změna mezi I.-II. měřením \\
\hline & počet/30s & počet/30s & \\
\hline TO 1 & 20 & 25 & zlepšení \\
\hline TO 2 & 11 & 13 & zlepšení \\
\hline TO 3 & 17 & 18 & zlepšení \\
\hline TO 4 & 13 & 11 & zhoršení \\
\hline
\end{tabular}

Jak vyplývá $\mathrm{z}$ Tab. 4, negativní změna v testu síly dolních končetin a dynamické rovnováhy nastala u TO 4, což přisuzujeme vlivu nadváhy a zdravotním problémům srdce (by-pass, operace chlopně). I po zhoršení dosahuje dle hodnocení Senior fitness testu percentil 50. V průběhu intervenčního programu byla nadváha TO 4 viditelně limitujícím faktorem pohybu. 
Tab. 5 Výsledky testu síly dolních končetin, dynamické rovnováhy a krátkodobé vytrvalosti - Step test

\begin{tabular}{|c|c|c|c|}
\hline TO & I. měření & II. měření & změna mezi I.-II. měřením \\
\hline & počet/2min & počet/2min & \\
\hline TO 1 & 65 & 87 & zlepšení \\
\hline TO 2 & 96 & 117 & zlepšení \\
\hline TO 3 & 128 & 112 & zhoršení \\
\hline TO 4 & 60 & 91 & zlepšení \\
\hline
\end{tabular}

Zaznamenané hodnoty Step testu poukazují na negativní změnu u TO 3 (Tab. 5). Při prozkoumání naměřených hodnot však vidíme, že i po zhoršení úrovně sledovaných pohybových schopností TO 3 dosahuje velmi dobrých výsledků. V př̀epočtu na percentil dle Senior fitness testu se dostáváme k hodnotě 94 . S úbytkem svalové hmoty $\mathrm{z}$ důvodu involučních změn dochází $\mathrm{k}$ úbytku síly a výkonnosti. U TO 1, TO 2 a TO 4 test síly dolních končetin a dynamické rovnováhy potvrdil zpomalení involučních změn a vliv pohybového programu.

Tab. 6 Výsledky testu dynamické rovnováhy, orientace v prostoru - Side step test

\begin{tabular}{|c|c|c|c|}
\hline TO & I. měření & II. měření & změna mezi I.-II. měřením \\
\hline & čas/s & čas/s & \\
\hline TO 1 & 31,22 & 39,11 & zhoršení \\
\hline TO 2 & 56,12 & 55,17 & bez změny \\
\hline TO 3 & 42,42 & 44,27 & zhoršení \\
\hline TO 4 & 38,15 & 54,5 & zhoršení \\
\hline
\end{tabular}

Mírné zhoršení výsledků uvedených v Tab. 6 poukazuje na vysokou koordinační náročnost testované dovednosti. Tyto negativní změny lze považovat za nepatrné. Z literatury (Havlíčková et al. 2004) víme, že koordinační schopnosti s věkem ubývají. Přesto jsme přesvědčeny, že existuje možnost udržení, popř. zlepšení některých koordinačních schopností potřebných v každodenním životě. Pozorováním jsme zjistily, že přísunné kroky stranou činily probandům potíže. Test vyžadoval maximální soustředěnost a schopnost motorického učení. Během testování jsme zjistily, že by bylo dobré v dalším zkoumání věnovat pozornost motorickému učení, které podle našeho subjektivního názoru je limitujícím faktorem pohybu v období senia.

Tab. 7 Výsledky testu dynamické rovnováhy SIMI-Motion - otevřené oči

\begin{tabular}{|c|c|c|c|}
\hline TO & I. měření & II. měření & změna mezi I.-II. měřením \\
\hline & dráha/m & dráha/m & \\
\hline TO 1 & 6,185 & 6,062 & zlepšení \\
\hline TO 2 & 6,287 & 6,129 & zlepšení \\
\hline TO 3 & 6,124 & 6,03 & zlepšení \\
\hline TO 4 & 6,177 & 6,115 & bez změny \\
\hline
\end{tabular}


Tab. 8 Výsledky testu dynamické rovnováhy SIMI-Motion - zavřené oči

\begin{tabular}{|c|c|c|c|}
\hline TO & I. měření & II. měření & změna mezi I.-II. měřením \\
\hline & dráha/m & dráha/m & \\
\hline TO 1 & 6,257 & 6,101 & zlepšení \\
\hline TO 2 & 6,213 & 6,07 & zlepšení \\
\hline TO 3 & 6,201 & 6,063 & zlepšení \\
\hline TO 4 & 6,271 & 6,137 & zlepšení \\
\hline
\end{tabular}

Jak vyplývá z Tab. 7 a 8, výsledky testu ukazují, jak intervenční program v souladu s aktivním způsobem života může ovlivnit dynamickou rovnováhu, a tím snížit nebezpečí pádu při běžných každodenních činnostech. Rovnováhové schopnosti ovlivňují mnoho aspektů - vestibulární aparát, zrakový aparát, proprioreceptory, kompenzační reakce, deformity skeletu, onemocnění kloubů atd. Již tento výčet ukazuje, jak náročné je v rámci involučních změn udržet rovnováhové schopnosti.

Tab. 9 Porovnání změn úrovně pohybových schopností pomocí testů dynamické rovnováhy

\begin{tabular}{|c|c|c|c|c|c|c|}
\hline TO/test/schopnost & $3 / \mathrm{PO}, \mathrm{DR}$ & \multicolumn{1}{c}{ 4/SDK, DR } & \multicolumn{2}{c|}{ 5/SDK, DR, KV } & $6 / \mathrm{PO}, \mathrm{DR}$ & \multicolumn{2}{c|}{ 7/DR } & 8/DR \\
\hline TO 1 & $\uparrow$ & $\uparrow$ & $\uparrow$ & $\downarrow$ & $\uparrow$ & $\uparrow$ \\
\hline TO 2 & $\uparrow$ & $\uparrow$ & $\uparrow$ & & $\uparrow$ & $\uparrow$ \\
\hline TO 3 & $\uparrow$ & $\uparrow$ & $\downarrow$ & $\downarrow$ & $\uparrow$ & $\uparrow$ \\
\hline TO 4 & $\uparrow$ & $\downarrow$ & $\uparrow$ & $\downarrow$ & & $\uparrow$ \\
\hline
\end{tabular}

Legenda: PO - prostorová orientace, DR - dynamická rovnováha, SDK - síla dolních končetin, KV krátkodobá vytrvalost. Testy: 3 - Food up and go test, 4 - Chair stand test, 5 - Step test, 6 - Side step test, 7 - SIMI-Motion - otevřené oči, 8 - SIMI-Motion - zavřené oči.

Pokusily jsme se porovnat výsledky testů dynamické rovnováhy (test 7 a 8 , Tab. 9) a testů zaměřených na vyhodnocení složitějších pohybů, při kterých sledujeme kromě dynamické rovnováhy i prostorovou orientaci, krátkodobou vytrvalost a sílu dolních končetin (testy 3-6, Tab. 9). Z výsledků vyplývá, že u TO 1 se zvýšila úroveň u všech sledovaných schopností s výjimkou testu č. 6 . Výsledek testu 6 (Tab. 9) ukazuje mírné zhoršení, které však přisuzujeme vysoké náročnosti testu. Z toho vyplývá, že TO 1 je i v 88 letech schopna do určité míry, v rámci svých motorických schopností, udržet i zvyšovat úroveň námi sledovaných schopností a využít je i v činnostech každodenního života. TO 2 dosáhla velmi uspokojivého výsledku ve všech testech monitorujících dynamickou rovnováhu, orientaci v prostoru, sílu dolních končetin a krátkodobou vytrvalost. I s limitujícími faktory pohybové činnosti (dna, nedostatečná činnost štítné žlázy, vysoký krevní tlak, nadváha) je schopna při pravidelném pohybovém programu zvyšovat úroveň námi sledovaných schopností, a tím přispět k plnohodnotnému životu. TO 3 žije v penzionu pro seniory, kde využívá vybraných služeb. Uvědomuje si nutnost pohybové aktivity a její výsledky testů to dokazují. Mírné zhoršení se projevilo v testu 5 a 6 , ale výsledné hodnoty jsou na velmi dobré úrovni (percentil v Senior fitness testu 94). Zhoršení v testech 5 a 6 nám nepotvrzuje zhoršení úrovně síly dolních končetin a prostorové orientace, nebot v dalších dvou testech $(3,4)$ monitorujících stejné pohybové schopnosti se úroveň zvýšila. Test 4 a 6 ukazuje mírné zhoršení TO 4. Ostatní testy nepotvrdily snížení úrovně určité pohybové schopnosti. Výsledky ukazují, s ohledem k zdravotnímu stavu (trojitý by-pass, cévní a zrakové potíže, nadváha), že správně zvolená pohybová aktivita involuční proces zpomaluje. Tyto výsledky bychom mohly připojit k zahraniční studii (Brown; Martinez; Parsons 2006, Muesel 1996), která potvrzuje, že intervenční hudebně-pohybové programy trénující kognitivní a motorické dovednosti snižují riziko demence, zpomalují involuční změny a udržují motorické kompetence pro každodenní mobilitu. 


\section{ZÁVĚRY}

Se zvyšujícím se průměrným věkem obyvatelstva se stále více pozornosti věnuje studiím o plnohodnotném životě seniorů. Studie se zaměřují na zpomalování involučních procesů. Mnoho výzkumů již dokázalo pozitivní vliv pohybu na tyto změny, ale vzhledem k individuálním zvláštnostem a zdravotním stavům jednotlivců je nelze zevšeobecňovat. $V$ prŕpadové studii jsme u jednotlivých probandů zjištovaly vliv intervenčního programu na vybrané motorické schopnosti. Hledaly jsme informace, které by mohly sledované schopnosti ovlivňovat. U TO 2, TO 3 a TO 4 se i po absolvování cíleného pohybového programu zhoršila úroveň statické rovnováhy. U žádného ze sledovaných probandů se nepotvrdilo snížení úrovně dynamické rovnováhy, prostorové orientace ani síly dolních končetin. Tyto výsledky jsou pro nás důkazem, že i u osob daného věku s prrítomností mnoha zdravotních komplikací lze pomocí vhodné pohybové intervence přispět ke zkvalitnění jejich života. Ve studiu budeme nadále pokračovat a shromaždovat další data, aby širší závěry byly přenositelné do dalších výzkumů.

\section{Literatura}

BROWN, S.; MARTINEZ, M. J.; PARSONS, L. M. The neutral basis of human dance. Cereb Cortex, 2006.

FETZ, F. Sensomotorisches Gleichgewicht im Sport. Wien: Österreichischer Bundesverlag, 1987. ISBN 3-215-06758-7.

DROPČOVÁ, V. Koordinačné schopnosti faktorom rozvoja pohybových zručností v rytmickej gymnastike. Teor. praxe těl. vých., 1987. roč. 35, č. 11, s. 682- 685.

HAVLÍČKOVÁ, L. et al. Fyziologie tělesné zátěže I. Praha: Karolinum UK, 2004. ISBN 80-7184-875-1. HENDL, J. Kvalitativní výzkum. Základní metody a aplikace. Praha: Portál, 2005. ISBN 80-7367-040-2. CHYTRÁČKOVÁ, J. Sledování výkonnosti československé mládeže v letech 1980-1984. In Ontogeneze lidské motoriky. Praha: Olympia, 1985, s. 119-123.

JAVŮREK, J. Balancování ve stoji I-III. Teor. praxe těl. vých., 1988. roč. 36, č. 5-7, s. 284-287.

KLÁROVÁ, R. et al. Pojd’si hrát s netradičním náčiním. Brno: Pedagogická fakulta MU, 1993.

KLÁROVÁ, R. Rozvoj koordinačních schopností dětí mladšiho školního věku. Habilitační práce. Brno: Masarykova univerzita. 1999.

KLEVETOVÁ, D.; DLABAČOVÁ, I. Motivační prvky při práci se seniory. Praha: Grada Publishing, a.s., 2008. ISBN 978-80-247-2169-9.

KOPŘIVOVÁ, J. Význam pohybu v procesu stárnutí. In Sport a kvalita života. Brno: Masarykova univerzita, 2005, s. 65. ISBN 80-210-3863-2.

KOSTADINOVÁ, A. Vztah motorické docility a vybraných psychických dispozic u gymnastek mladšího školního věku. Kandidátská disertační práce. Praha: FTVS UK, 1989.

MĚKOTA, K. Měření a testy v antropomotorice III. Olomouc: Rektorát Univerzity Palackého, 1979.

MOENHLE, A. Praktikum der Elektronystagmographie und Cranio-Corpo-Graphie. Berlin: Quintessenz Verlags GmbH, 1987. ISBN 3876529905.

MUESEL, H.; BEWEGUNG, J. Sport und Gesundheit im Alter. Gerontologie - Geriatrie. Wiesbaden: Meyer, 1996.

RHEINWALDOVÁ, E. Novodobá péče o seniory. Praha: Grada, 1999. ISBN 80-7169-828-8.

RIKLI, R. E.; JONES, C. J. Senior fitness test manual. United Kindgdom: Human kinetics, 2001. ISBN 0-7360-3356-4.

ŠIMONEK, J., ZAPLETALOVÁ, L. Koordinačné schopnosti. In Koordinačné schopnosti. Bratislava: ÚV ČSZTV, 1985.

ŠTILEC, M. Program aktivního stylu života pro seniory. Praha: Portál, 2004. ISBN 80-7178-920-8.

WILHELM, Z. et al. Stručnýp řehled fyziologie člověka pro bakalářskéstudijní programy. Brno: Masarykova univerzita, 2003. ISBN 80-210-2837-8.

ZIMMELOVÁ, P. Úrazy seniorů - prevence a př́činy. Prevence úrazů, otrav a násilí. Praha: 2005. ISSN 1801-0261. 